\title{
A Review on the Behaviour of Combined Stone Columns and Pile Foundations in Soft Soils when Placed under Rigid Raft Foundation
}

\author{
Danish Ahmed ${ }^{1,2 *}$, Siti Noor Linda bt Taib ${ }^{1}$, Tahar Ayadat ${ }^{2}$ and Alsidqi Hasan ${ }^{1}$ \\ ${ }^{I}$ Faculty of Engineering, Universiti Malaysia Sarawak, Malaysia \\ ${ }^{2}$ College of Engineering, Civil Engineering Department, Prince Mohammad bin Fahd University,
}

\section{Saudi Arabia}

\begin{abstract}
In the last few decades, it has been observed that raft foundations are very commonly used as a foundation solution for moderate to high rise structures either by resting on stone columns or on piles in soft soils. It is believed that, combining stone columns and piles in one foundation system is the more suitable foundation for medium rise structures. The combined foundation system provides a superior and more economical alternative to pile, and a more attractive alternative to stone columns in respect to ground improvement. This paper presents the review of existing studies reported in the literature in the last two decades about the behaviour of stone columns under raft foundations and piled raft foundation in soft soil, notably the failure mechanism and the bearing capacity. Also, a limited work from the literature concerning the performance of combined (pile/stone columns) foundation system in soft soil is comprised. Furthermore, very extensive ongoing research work regarding the investigation and study on the performance of combined (pile/stone columns) foundation system in soft soils is discussed. The main goals and methodology to study the performance of the combined (pile/stone columns) foundation systems in soft soil are also addressed.
\end{abstract}

Keywords: behaviour; stone columns; piled; raft foundation; soft soil

\section{INTRODUCTION}

Nowadays, construction of medium to high rise buildings are very common due to the expansion and development of urban areas. The foundation system required for such buildings are raft foundations either on the ground improved with stone columns or resting on piles. Piles are employed on soft soils on which foundations have low bearing capacity and high consolidation settlement. They carry load through soft soil to firm stratum through bearing and/or side friction. They are usually deployed for cases of large loads (such as high rise building) applied on poorly densified soils. However, advance planning and heavy equipment are required for driving them. Stone columns consist of crushed coarse aggregates of various size compacted in long cylindrical holes in the ground to ameliorate the performance of soft soils and the rate of consolidation. When installed, stone columns modify the original soil to a composite ground of low compressibility and high shear strength. They are simple and cost-saving alternative. They are best suited for low-rise loaded industrial structures. Combining stone columns and piles in one foundation system, definitely improve the carrying capacity of the system, accelerate the rate of consolidation of the soil foundation, modify the soil foundation to a new upgraded composite ground, and certainly reduce the cost of the geotechnical works (Manojit Samanta \& Riya Bhowmik, 2017). It can be advanced that the combined foundation system provides a superior and more economical alternative to pile, and a more attractive alternative to stone columns in respect to ground improvement and amelioration of the 
performance of soil foundation. It is believed that the combined foundation is the more suitable foundation for medium rise structures.

This paper reviews the research works reported in literature in the last two decades concerning the behaviour of stone columns with raft foundation and piled raft foundation in soft soils, notably the failure mechanism and the bearing capacity. The very limited work performed on the behaviour of combined foundation system (use of stone columns and piles together under raft foundation) in soft soils is also included. Moreover, the most recent extensive research program which is in progress (Ahmed, 2019) is described. The work was established in order to study the performance of combined (pile/stone columns) foundation system in soft soils. The main goal and methodology which will be used to study the performance of such foundation system in soft soils are discussed.

\section{BEHAVIOUR OF STONE COLUMNS AND PILES UNDER RAFT FOUNDATION IN SOFT SOILS}

\section{A. Stone Columns Under Raft Foundation}

Stone columns are made of granular material compacted in the cylindrical hole in the ground to improve the performance of soft soils. They are very effective for light load structures and less effective for supporting heavy loads. Whereas, piles foundations are long, slender elements made of concrete, steel, timber, or polymer used to support structural loads, to transfer structural loads to deeper rock or firm soil layers at sites where soft clay exist at shallow depth, to absorb tensile and lateral loads, to support loads by shaft resistance, and to reduce the settlement of mat foundations.

In 1830 the French military engineers used the stone columns for the first time when they had to support the foundation of iron works at the artillery arsenal which was constructed by filling crushed lime stone in the holes created by driving the stakes on the deposits of the soft estuarine in Bayonne (Moreau et al., 1835) each column supported the $10 \mathrm{kN}$ load having the size of $0.2 \mathrm{~m}$ diameter and $2 \mathrm{~m}$ length. Later it was used in 1930's partially as the result of vibroflotation (a technique for compacting the granular soil), according to Steuermam (1939) forming of compacted granular columns under the granular soil could have doubled the bearing capacity of soil. In early 1960s, the vibroflotation technique was used to treat the compressible soils (Dullage, 1969) by placing the stone columns directly under the loaded footings in a grid formation.

This section reviews the work performed during the last two decades on the behaviour and performance of stone columns when placed in soft soils under raft foundation. Then the most important works carried out on the piled raft foundation in soft soils are briefly summarized.

Hughes and Withers (1974) were among the first one who carried out the laboratory experiments on single granular columns and described that columns fail individually by bulging. Moreover, they introduced the concept of the unit cell to predict the capacity of a stone column. They also suggested that the bearing capacity of a group of stone columns can be taken as the sum of the capacity of individual columns. Priebe (1976), Goughnour and Bayuk (1979), Balaam and Booker (1981), Barksdale and Bachus (1983), and Poorooshasb and Meyerhof (1997) utilized the unit cell concept to develop theoretical models to predict the bearing capacity of stone columns. However, because they didn't consider the effect of columns interaction in the group, many inconsistency and dissimilarities were observed in the literature between experimental data and their theoretical results.

Hu et al. (1997) conducted an experimental investigation on a group of stone columns and concluded that the group of stone columns fails in a conical shape. Among others, Wehr (1999), Wood et al. (2000), and Bae et al. (2002) confirmed based on a numerical study using the finite element that the group of stone columns fails in conical shape because of column interaction. Few years later, Hanna et al. (2013) conducted a numerical investigation to study the performance and failure mechanism of a group of stone columns under raft foundation in soft clay using PLAXIS 2D. Based on a parametric study they have concluded that with an increase in the angle of shearing resistance of stone columns, the foundation carrying capacity increases. For the mode of failure, it was observed that when the area replacement ratio is less than $10 \%$, columns fails due to bulging and massive shear failure occurs when area replacement ration ranges between $10 \%$ to $35 \%$ (Figure 1). 
Based on the failure mechanism results, design charts were provided to predict the mode of failure (punching, local or general shear failure) for the group of stone columns under raft foundation (Figure 1).

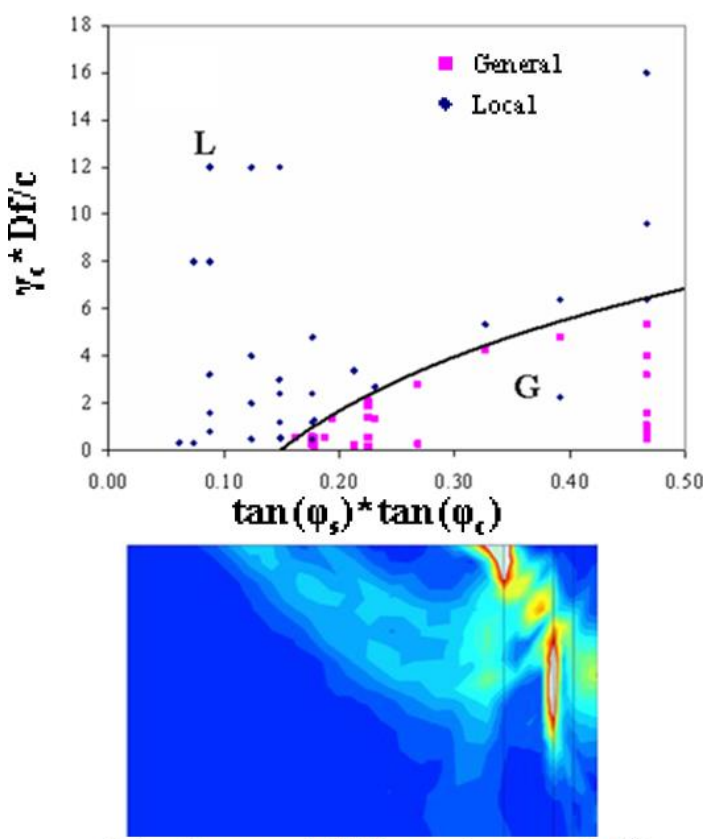

(a) General failure (named G)

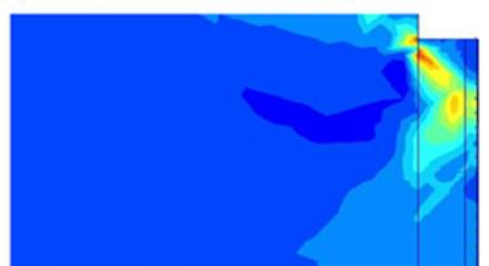

(b) Local failure (named L)

Figure 1. Design chart and failure modes for As $=35 \%$ and $\mathrm{d} / \mathrm{B}=0.4$ (Hanna et al., 2013)

Nazari et al. (2014) introduced a simple analytical model for the estimation of the ultimate bearing capacity of a stone column. The model was then validated and verified using finite element method. According to them, the bearing capacity of a stone column increases with the angle of shearing resistance of the stone and the diameter of the columns and decreases with the increase in centre to centre distance between the columns. Ziaie et al. (2016) conducted numerical finite element simulations on the use of stone columns under raft foundation. They reported that a group of stone columns under static loading fails due to bulging near the centre of the footing and fails due to lateral deformation near to the edge of raft foundation. Fattah et al. (2017) have developed a generalized equation to estimate the carrying capacity of the floating group of stone columns installed in clay with different diameters and L/D ratios.

Similarly, many other investigations and studies have been performed using analytical and numerical methods to investigate the behaviour/performance of stone columns in soft soil under raft foundation (among others, Jorge Castro, 2014; Micheal et. al., 2014; Mohamed et al., 2016). Generally, they all concluded that with the increase in column friction angle, strength, stiffness, diameter, length, area replacement ratio, and decrease in column spacing the bearing capacity of the foundation system can increase considerably as shown in Figure 2. Whereas, the length of the stone columns has not much effect on the performance of the foundation after a certain limit.

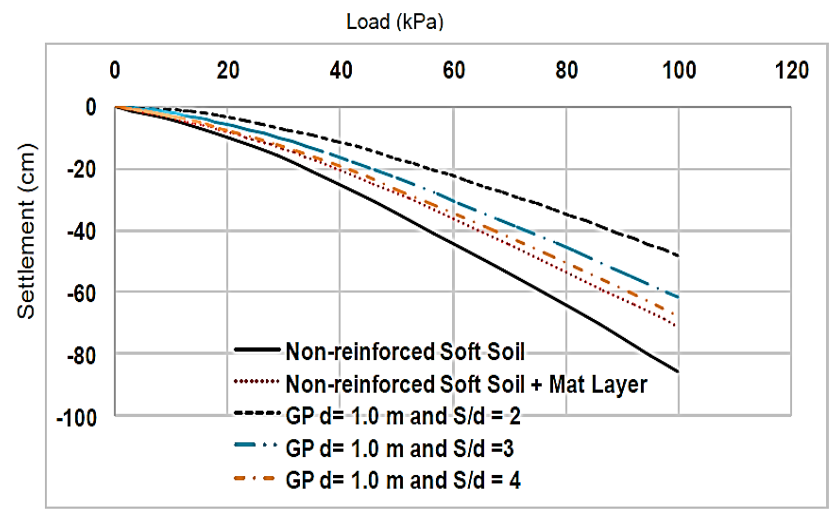

Figure 2. Load Vs settlement curves for the treated and nontreated soft soil with different spacing ratios (Mohamed et

$$
\text { al., 2016) }
$$

\section{B. Piles Under Raft Foundation}

Concerning piled raft foundation, many researchers carried out either experimental, theoretical and/or numerical study to investigate the behaviour and performance of this type of foundation in soft soils, Jaeyeon et al. (2012) conducted a $3 \mathrm{D}$ numerical investigation on piled raft foundation in soft and stiff clay subjected to vertical loading. A series of the parametric study was performed on the piled raft foundation to investigate the performance and to evaluate the loaddisplacement response of piled raft foundation. They concluded that the wider spaced pile groups with the same number of piles and diameter can reduce the average settlement and increase the carrying capacity of the piled raft foundation. Likewise, Shivanand et al. (2019) carried out a parametric study on piled raft foundation in clay, using 
the finite element program Plaxis $3 \mathrm{D}$, the performance of piled raft foundation in uniform and varying soil profile. It was reported that the average settlement of piled raft decreases by increasing the width of piles. They confirmed that the average settlement is independent of the number of piles in the uniform soil profile, but it decreases with the increase in piles' number in varying soil. Most of the researches and investigations focused on studying the settlement characteristics of piled raft foundation with various arrangements of the pile. It was reported that with the increase in pile length, pile diameter, aspect ratio, number of piles and raft foundation thickness the overall performance of piled raft foundation can be improved considerably (among others, Luca de Sanctis \& Alessandro Mandolini, 2006; Poulos et. al., 2011; Srilakshmi \& Darshan, 2013; Chung Nguyen et. al., 2013; Balakumar et. al., 2013, Prashant et. al., 2013; Anhtuan et. al., 2014; Paravita et. al., 2015; Kazimierz et. al., 2015; and Elwakil \& Azzam, 2016). Figure 3 shows the effect of pile spacing on the maximum settlement of a piled raft foundation, where it can be observed that the foundation settlement increases with the increase in pile spacings.

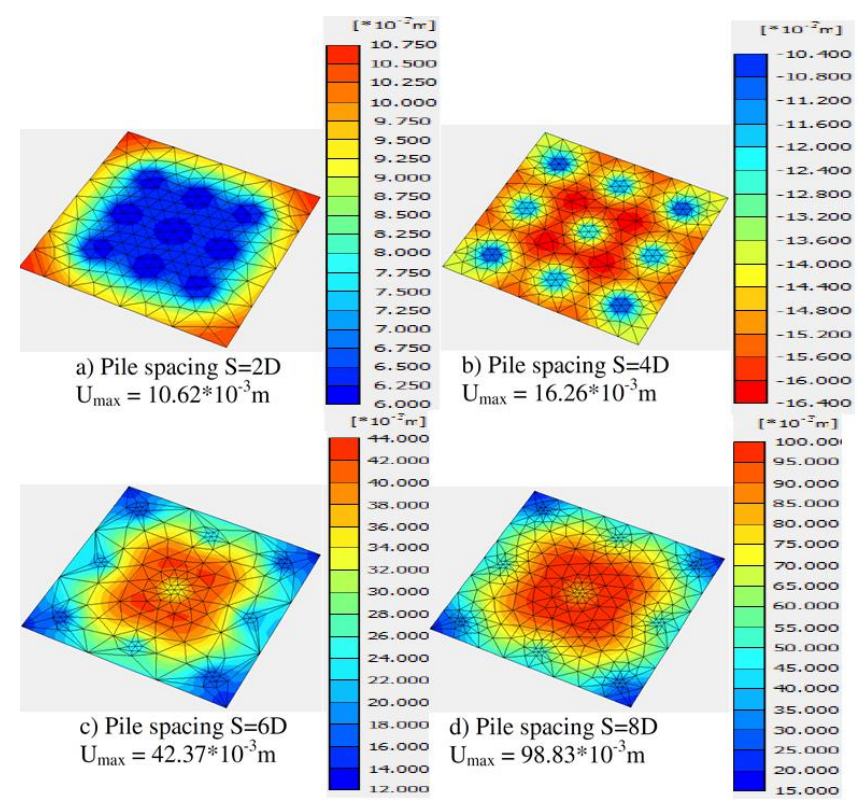

Figure 3. Influence of pile spacing on the maximum settlement ( $\left.U_{\max }\right)$ of the foundation (Anhtuan et al., 2014)

As stated previously, stone columns are One of the treatment method for weak soils, which are mostly used to improve the strength and consolidation characteristics of the weak and compressible soils. They are quite opposite of the pile foundations, stone columns are very effective for the soils near to the surface and also they are very ideal for supporting the foundations of light weight structures. There are many cases reported where stone columns were used successfully as the foundation solution.

However, their use is not a hundred percent successful, notably when used in clayey soils having undrained shear strength $\mathrm{Cu} \leq 25 \mathrm{kPa}$. In some cases, their use without precautions ended with failure (Mc Kenna, 1975, Machado Filho, 1987, and many other unpublished cases). For this reason, in many cases pile foundation system was applied. Deep foundation (piles) are very effective for heavy structures because piles penetrate through the weak soil deposits to the stiff soil or bed rock to support the structure's weight. However, piles foundations are more expensive than stone columns improving methods and quite often economically impacts on the construction projects' expenses. In order to overcome this complex problem a combination of stone columns and pile foundation together in one foundation system seems to be the more appropriate and promising solution.

Very limited work was reported in investigating the behaviour of combined stone columns and pile foundation system in soft soils (Manojit Samanta \& Riya Bhowmik, 2017). Manojit et al. conducted a numerical analysis of the piled raft foundation in soft soil improved with stone columns. PLAXIS 3D was used to study the influence of parameters on the total and differential settlements of the foundation. They concluded that the change in length, spacing, friction angles, area replacement ratio, the diameter of stone columns/piles and the thickness of raft can change the percentage of shared load on the stone columns and piles Figure 4. They also recommended that a detailed parametric study is required for the optimisation of foundation configuration and designing the economical foundation system (stone columns and piles under raft in soft soil).

Based on the existing researches, it is identified that the behaviour and performance of the combined foundation system in soft soil have not been investigated thoroughly. Available literature shows that no work has been performed to investigate the mode of failure of such foundation system, 
no analytical model or design procedure are available to design the combined foundation system. Furthermore, no arrangement of stone columns and piles are proposed for the optimisation of the performance of this combined foundation system under raft foundation in soft soil.

Generally, single pile fails by end bearing and/or shearing along its whole length (slippage). Group of piles fail either as a block by general shear failure (Poulos et al., 2011), or by bearing at the tip of the piles and also by shear along the side of the piles group. The failure by shear has a trapezoidal form, which can be considered in 2-D plan as straight line (Ahmed et al., 2020). Whereas, single stone column fails by bulging at shadow depth, typically less than 4 to 6 diameters (Hughes \& Withers, 1974). Group of stone columns in soft soils fail by punching, local shear or general shear failure (Hanna et al., 2013).

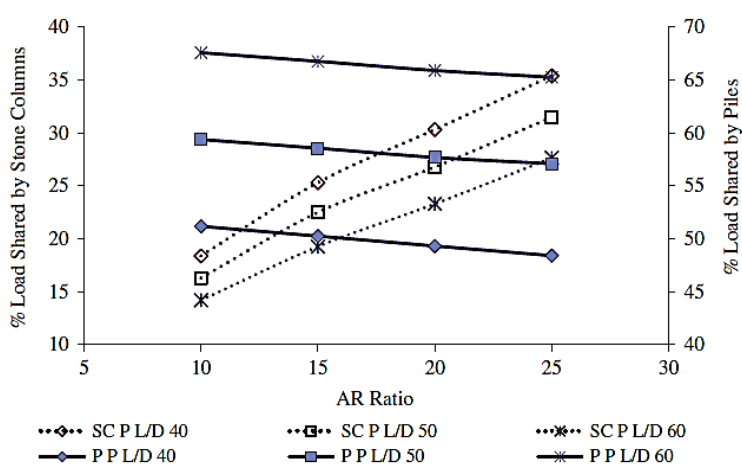

Figure 4. Load sharing capacity of piles and stone columns for different slenderness ratio in soils (Manojit Samanta \& Riya Bhowmik, 2017)

\section{PROPOSED STUDY: PERFORMANCE OF COMBINED (PILE/STONE COLUMNS) FOUNDATION SYSTEM IN SOFT SOILS.}

As stated previously, combining stone columns and piles in one foundation system is the more suitable foundation for medium rise structures. The combined foundation system provides a superior and more economical alternative to pile, and a more attractive alternative to stone columns in respect to ground improvement. Recently, Ahmed (2019) has conducted an extensive research program to study the performance of combined (pile/stone columns) foundation system in soft soils Figure 5 . The methodology used to treat this subject is based on numerical investigation and analysis using PLAXIS 3D. The main goals of this research can be summarized as follows:

1- Development of numerical models to investigate the performance of (a) stone columns under raft foundation, (b) piled raft foundation, and (c) combined foundation system (i.e. stone columns/piles capped with rigid raft foundation) in soft clayey soil.

2- Parametric study will be performed using the three developed numerical models. Different configurations will be investigated (i.e. different diameters and spacing, different ratio of piles to stone columns area, different soil parameters, etc.). Furthermore, the results of the parametric study will be used to investigate the failure mechanism of the combined foundation system and to compare it to the existing failure mechanisms of other foundation systems reported in the literature (such as piled raft foundation and stone columns under raft foundation).

3- Optimisation of the configuration stone columns/piles in the combined foundation system which lead to the most effective performance of this foundation system in soft clayey soil.

4- Development of an analytical model to predict the carrying capacity of the combined foundation system capped with rigid raft foundation in soft clayey soil. The developed analytical model will depend mainly on the observed failure mechanism.

5- Proposition of a design procedure for the combined foundation system in soft clayey soil.

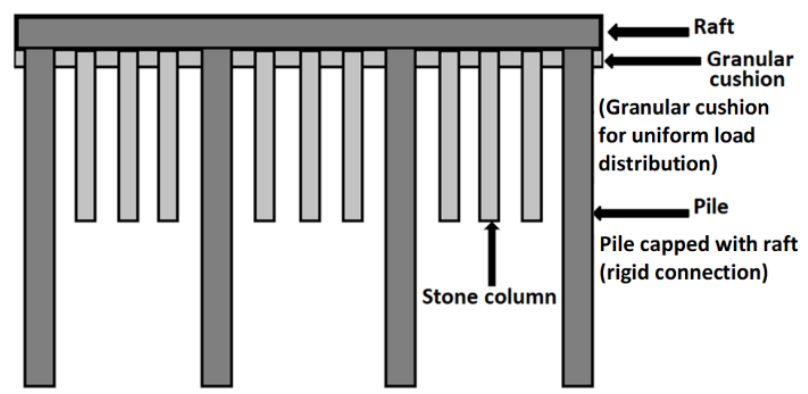

Figure 5. Conceptual diagram for combined stone columns/piles capped with raft foundation

The main preliminary results concerning the investigation of the performance of group piles installed in soft soils under a raft foundation are summarized as follows (Ahmed et al., 2020): 
1. The ultimate carrying capacities of the piled raft foundation decreased by increasing in the ratio spacing/diameter $(S / D)$.

2. The piles spacing significantly affect the performance of the piled raft foundation on soft soil. It was noted that, when the ratio $S / D$ is greater than 10 (i.e. $\mathrm{S} / \mathrm{D}>10$ ), the influence of piles on the ultimate carrying capacity of piled raft foundation is not significant.

3. The piled raft foundation system fails by bearing at the tip of the piles and also by shear along the side of the piles group. The failure by shear has a trapezoidal form, which can be considered in 2-D plan as straight line.

4. Based on the observed failure mechanism, an efficiency factor of the ultimate carrying capacity of a piled raft foundation was proposed (Ahmed et al., 2020). Furthermore, based on the parametric study, a semiempirical model to predict the ultimate carrying capacity of the piled raft foundation was developed (Ahmed et al., 2020).

\section{CONCLUSION}

In this paper, a review on the work performed during the last two decades on the behaviour and performance of stone columns when placed in soft soils under raft foundation was presented. Then the most important works carried out on the piled raft foundation in soft soils were briefly summarized. The very limited work conducted on combined (pile/stone columns) foundation system was described briefly.

The most recent extensive research program (in progress) conducted to study the performance of combined (pile/stone columns) foundation system in soft soil was examined. The main goal and methodology which will be used to study the performance of combined (pile/stone columns) foundation system in soft soils were discussed. The main features of this research program are to investigate the failure mechanisms of the combined foundation systems, to optimise the configuration stone columns/piles in the combined foundation system which lead to the most effective performance of this foundation system in soft clayey soil. Additionally, to develop an analytical model to predict the carrying capacity of the combined foundation system capped with rigid raft foundation in soft clayey soil, and finally to propose a design procedure for combined foundation system in soft clayey soil.

The main preliminary findings of this ongoing investigation indicated that the piled raft foundation system fails by bearing at the tip of the piles and also by shear along the side of the piles group. The failure by shear has a trapezoidal form, which can be considered in 2-D plan as straight line. Furthermore, based on the observed failure mechanism, an efficiency factor of the ultimate carrying capacity of a piled raft foundation was proposed. In addition, based on the parametric study, a semi-empirical model to predict the ultimate carrying capacity of the piled raft foundation was developed.

\section{ACKNOWLEDGEMENT}

The authors would like to extend appreciation to Universiti Malaysia Sarawak and Prince Mohammad bin Fahd University.

\section{REFERENCES}

Anhtuan, V, Ducphong, P, Tuonglai, N \& Yu, H 2014, '3D finite element analysis on behaviour of piled raft foundations', Applied Mechanics and Materials, vol. 580583 , pp. 3-8.

Ahmed, D 2019, 'Geotechnical performance of combined stone columns/piles capped with reinforced concrete raft foundation in soft clay soil', $\mathrm{PhD}$ thesis proposal, Universiti Malaysia Sarawak (UNIMAS).
Ahmed, D, Linda bt Taib, SN, Ayadat, T \& Hasan, A 2020, 'Numerical investigation on the performance of Piled Raft Foundation in Soft Clayey Soils', $5^{\text {th }}$ World Congress on Civil, Structural, and Environmental Engineering (CSEE'20), Lisbon, Portugal.

Afshar, NJ \& Ghazavi, M 2014, 'A simple analytical method for calculation of bearing capacity of stone-column', International Journal of Civil Engineering, vol. 12, no. 1, Transaction B: Geotechnical Engineering. 
Balaam, NP \& Booker, JR 1981, 'Analysis of Rigid Raft Supported by Granular Piles', Int. Jour. Num. Anal. Meth. Geomech, vol. 5, pp. 379-403.

Barksdale, RD \& Bachus, RC 1983, Design and Construction of Stone Columns, Volume 1, Report No. FHWA/RD83/o26, Federal Highway Administration, USA.

Bae, WS, Bang, WS \& Byung, CA 2002, 'Behavior of foundation system improved with stone columns', Proc. 12th Int. Offshore and Polar Engineering Conf, Kitakyushu, Japan, pp. 675-678.

Balakumar, V, Oh, E, Bolton, M \& Balasubramaniam, AS 2013, 'A design method for piled raft foundations', Proceedings of the 18th International Conference on Soil Mechanics and Geotechnical Engineering, Paris.

Cho, J, J, Lee, JH, Sangseom Jeong, Jaehwan Lee 2012, 'The settlement behavior of piled raft in clay soils', Ocean Engineering, vol. 53 (2012), pp. 153-163.

Castro, J 2014, 'Numerical modelling of stone columns beneath a rigid footing', Computers and Geotechnics, vol. 60, pp. $77-87$.

De Sanctis, L \& Mandolini, A 2006, 'Bearing capacity of piled rafts on soft clay soils', Journal of Geotechnical and Geo-environmental Engineering.

Dullage, CR 1969, 'An investigation into the feasibility of small-scale tests on granular piles in clay', $\mathrm{PhD}$ thesis, University of Wales, Swansea.

Elwakil, AZ \& Azzam, WR 2016, 'Experimental and numerical study of piled raft system', Alexandria Engineering Journal, vol. 55, pp. 547-560.

Elsawy, M \& El-Garhy, B 2016, 'Behavior of raft foundation resting on improved soft soil with conventional granular piles', Journal of Scientific and Engineering Research, vol. 3, no. 4, pp. 428-434.

Fattah, MY, Al-Neami, MA \& Al-Suhaily, AS 2017, 'Estimation of bearing capacity of floating group of stone columns', Engineering Science and Technology, an International Journal, vol. 20, pp. 1166-1172.

Goughnour, RR \& Bayuk, AA 1979, 'Analysis of stone column - soil matrix interaction under vertical load', Proc. Int. Conf. on Soil Reinforcement: Reinforced Earth and Other Techniques, Paris, France, vol. 1, pp. 271-278.

Hughes, JM, Withers, N, J 1974, 'Reinforcing of soft cohesive soils with stone columns', Ground Engineering, vol. 7 , no. 3, pp. 42-49.

Hu, W, Wood, DM \& Stewart, W 1997, 'Ground improvement using stone column foundations: result of model tests', Int. Conf. on Ground Improvement Techniques, pp. 247-256.

Hanna, AM, Etezad, M \& Ayadat, T 2013, 'Mode of failure of a group of stone columns in soft soil', International Journal of Geomechanics (ASCE), vol. 13, pp. 87-96.

Kazimierz, J, Artur, Z, Maciej, M \& Tomasz, P 2015, 'Numerical modelling and bearing capacity analysis of pile foundation', XXIV R-S-P seminar, Theoretical Foundation of Civil Engineering(24RSP) Procedia Engineering, vol. 111, pp. 356-363.

McKenna, JM, Eyre, W, A \& Woistenholme, DR 1975, 'Performance of an embankment supported by stone columns in soft ground', Geotechnique, vol. 25, no. 1, pp. 51-60.

Machado Filho, OVB 1987, 'Experimental study of a test fill founded on stone columns', Proc. of the Tnt. Symposium of Geot. Engng of Soft Soils, Mexico, vol. 1, pp. 249-256.

Micheál, MK \& Bryan, A, McCabe 2014, 'Settlement performance of pad footings on soft clay supported by stone columns: a numerical study', Soils and Foundations, vol. 54, no. 4, pp. 760-776.

Manojit, S \& Riya, B 2017, '3D numerical analysis of piled raft foundation in stone column improved soft soil', International Journal of Geotechnical Engineering.

Mali, S \& Singh, B 2019, 'Behavior of large piled raft foundation on different soil profiles for different loadings and different pile raft configurations', Technical paper Innovative Infrastructure Solutions, (Springer) 4:8.

Moayed, Z \& Haji, RMB 2016, 'Circular raft footings strengthened by stone columns under static loads', International Journal of Civil, Environmental, Structural, Construction and Architectural Engineering, vol. 10, no. 9. Neil, M \& Mary 1835, 'Foundations-emploi du sable', Annales des Ponts et Chaussees, Memoires, no. 224, pp. 171-214.

Nguyen, DDC, Kim, D, SK \& Jo, SB 2013, 'Parametric study for optimal design of large piled raft foundations on sand', Computers and Geotechnics.

Priebe, HJ 1976, 'Abschätzung Des SetzungsverhaltensEinesDurchStopfverdichtungVerbesser tenBaugrundes', Die Bautechnik, vol. 53, H.5, pp. 160-162 (In German).

Poorooshasb, HB \& Meyerhof, GG 1997, 'Analysis of behavior of stone columns and lime columns', Computers and Geotechnics, vol. 20, no. 1, pp. 47-70.

Poulos HG, Small, JC \& Chow, H 2011, 'Piled raft foundations for tall buildings', Geotechnical Engineering 
Journal of the SEAGS \& AGSSEA, vol. 42, no. 2, ISSN 0046-5828.

Prashant, G, Harvinder, S \& Jagadanand J 2013, 'Optimisation of piled-raft foundation', UKIERI Concrete Congress - Innovations in Concrete Construction.

Paravita, S, W \& Daniel, T 2015, 'Analysis of piled raft foundation on soft soil using PLAXIS 2D', The 5th International Conference of Euro Asia Civil Engineering Forum (EACEF-5) Procedia Engineering, vol. 125, pp. 363-367.

Steuerman, S 1939, 'A new soil compaction device', Engineering News Record, July 2oth.

Srilakshmi, G \& Darshan, M, N, S 2013, 'Analysis of piled raft foundation using finite element method', Int. J. Engg. Res. \& Sci. \& Tech. ISSN 2319-5991, vol. 2, no. 3.

Wehr, W 1999, 'Schottersäulen - das verhalten von einzelnensäulen und säulengruppen', Geotechnik, vol. 22, no. 1, pp. 40-47. (In German).

Wood, DM, Hu \& W, Nash, W 2000, 'Group effects in stone column foundations: model tests', Geotechnique, vol. 50, no. 6 , pp. $689-698$. 